\title{
Physical therapy performance in the rehabilitation of survivors of the Kiss nightclub tragedy: an experience report
}

\author{
Atuação da fisioterapia na reabilitação dos sobreviventes \\ da tragédia na boate Kiss: relato de experiência
}

Isabella Martins de Albuquerque, Maria Elaine Trevisan, Adriane Schmidt Pasqualoto,
Ana Lucia Cervi Prado, Marisa Bastos Pereira, Ana Fátima Viero Badaró*

Universidade Federal de Santa Maria (UFSM), Santa Maria, RS, Brazil

\begin{abstract}
Introduction: As a result of a fire in the Kiss nightclub that occurred in the city of Santa Maria - RS, 242 people were killed, of whom 235 died on the day of the episode, asphyxiated by the inhalation of toxic smoke. Approximately 1,000 more were injured. Objective: To report the experience of a group of physical therapists, professors at the Federal University of Santa Maria (UFSM), in the rehabilitation of survivors of the fire, victims of burns and inhalation injury. Materials and methods: Quantitative and qualitative study, in which an evaluation protocol of physical functional ability was designed to identify rehabilitation needs. Results: Two hundred seventy patients (147 men, mean age $26.72 \pm 9.5$ years) were examined, of which approximately $70 \%$ had some type of clinical modification or functional impairment that indicated the need for rehabilitation. The most prevalent respiratory signs and symptoms were: dry or productive cough (59.2\%); abnormal respiratory pace (11.4\%); fatigue (35.92\%); dyspnea (17.7\%); and chest pain
\end{abstract}

* IMA: PhD, e-mail: albuisa@gmail.com MET: PhD, e-mail: elainetrevisan@yahoo.com ASP: PhD, e-mail: aspasqualoto@hotmail.com ALCP: PhD, e-mail: analucia459@hotmail.com MBP: PhD, e-mail: masapg61@yahoo.com.br AFVB: PhD, e-mail: badaroana@uol.com.br 
(16.6\%). Neurological symptoms such as persistent headache (88.51\%), memory loss (11.4\%), and paresthesia (8.1\%) were also reported. Musculoskeletal injuries (14.7\%) and extensive burns (8.8\%) were also observed. One hundred and eighty-nine patients were referred to outpatient physical therapy and, of these, 22 still remain at the Outpatient Physical Therapy Unit of the University Hospital of (HUSM). Conclusions: Despite the vast professional experience of this group of physical therapists, the situations experienced were unique and unprecedented, both professionally and personally, and reinforced the importance of joining forces within an emergency care unit, as well as the importance of comprehensive and multi-professional outpatient monitoring.

Keywords: Rehabilitation. Smoke inhalation injury. Carbon monoxide. Hydrogen cyanide. Burns.

\section{Resumo}

Introdução: Em decorrência do incêndio na Boate Kiss, ocorrido na cidade de Santa Maria-RS, 242 pessoas foram a óbito, das quais 235 no dia do episódio, asfixiadas pela inalação de fumaça tóxica e, aproximadamente, outras 1000 ficaram feridas. Objetivo: Relatar a experiência de um grupo de fisioterapeutas, docentes da Universidade Federal de Santa Maria (UFSM), na reabilitação dos sobreviventes do incêndio, vítimas de lesão inalatória e queimaduras. Materiais e métodos: Estudo de caráter quanti-qualitativo, em que foi elaborado um protocolo de avaliação da capacidade físico-funcional para identificar a necessidade de reabilitação. Resultados: Foram avaliados 270 pacientes (147 homens, média de idade de 26,72 \pm 9,5 anos), sendo que aproximadamente $70 \%$ manifestaram algum tipo de alteração clínica ou comprometimento funcional que indicou a necessidade de reabilitação. Os sinais e sintomas respiratórios mais prevalentes foram: tosse seca ou produtiva (59,2\%), fadiga (35,92\%), dispneia $(17,7 \%)$, dor torácica $(16,6 \%)$ e alteração do ritmo respiratório (11,4\%). Sintomas neurológicos tais como dor de cabeça persistente $(88,51 \%)$, perda de memória $(11,4 \%)$ e parestesia $(8,1 \%)$ também foram relatados. Lesões musculoesqueléticas $(14,7 \%)$ e queimaduras extensas $(8,8 \%)$ também foram observadas. Cento e oitenta e nove foram encaminhados para tratamento fisioterapêutico em nível ambulatorial sendo que destes, 22 permanecem em atendimento no Ambulatório de Fisioterapia do Hospital Universitário de Santa Maria (HUSM). Conclusão: Apesar da extensa experiência profissional deste grupo de fisioterapeutas, as situações vivenciadas foram singulares e inéditas, tanto do ponto de vista profissional quanto pessoal e reforçou a importância da união de uma equipe no cuidado emergencial, bem como no acompanhamento ambulatorial multiprofissional e integrado.

Palavras-chave: Reabilitação. Lesão por inalação de fumaça. Monóxido de carbono. Cianeto de hidrogênio. Queimaduras.

\section{Introduction}

On January 27, 2013, the city of Santa Maria was astonished by a major disaster - a fire at the Kiss nightclub. This tragedy killed 242 people (1), of whom 234 died in the fire (2), suffocated by the inhalation of toxic smoke. Approximately another 1,000 were injured. Poisoning by carbon monoxide (CO) and hydrogen cyanide (HCN), as a result of the combustion of polyurethane foam used for acoustic insulation on the ceiling, was confirmed by technical reports of the General Institute of Expertise (3).

This was the second biggest tragedy resulting from fire in Brazil. The first occurred in Niterói, Rio de Janeiro, at the Gran Circus Norte-Americano in 1961, in which 503 died $(4,5)$. On a global level, it is the second largest fire to occur in a nightclub, if we consider the number of injured people and casualties, only behind the fire at the Coconut Grove in Boston in 1942, with 498 deaths and 170 people injured (6). The characteristics of the Kiss nightclub fire were similar to those of the República de Cromagnon in Argentina in 2004, with 194 casualties and 744 people injured (7).

Among the survivors of the Kiss nightclub tragedy, 34 were immediately admitted to the city hospital, in medium complexity admission units, and 88 other patients were admitted to intensive care units (ICUs), 
with severe inhalation injuries and burns of different extents. In most cases, these injuries were associated with musculoskeletal trauma of moderate severity, as the result of the physical effort made to leave the place.

In the early days after the tragedy, the number of cases increased, as a result of late manifestation of symptoms, as well as the occurrence of complications in the clinical picture. The most serious burn cases were immediately referred to the hospitals of the state capital, which specializes in the treatment of burns. Thus, in the first week, 45 patients were hospitalized in Santa Maria and another 26 in Porto Alegre. In addition, many patients were treated in the outpatient department and remained under observation, with the recommendation to return to the hospital in the event of changes in symptoms.

Immediately after the tragedy, the National Force of the Unified Health System (SUS, as per its acronym in Portuguese) contributed to the reorganization of health services available in Santa Maria and in the state, from immediate services to the definition of health care protocols. Priority was given to clinical, hospital, and psychosocial care, due to the high number of admissions, the severity of cases, and the emotional consequences of the tragedy, not only to the victims but also to relatives, friends, and the population in the area.

Considering the various post-admission effects, outpatient follow-up was necessary and urgent. In addition to the physical, emotional, social, and economic effects found in the short term, other possible late complications were foreseen as a result of exposure to toxic smoke and trauma, especially those of a psycho-emotional nature. Worthy of note that severe burns may have medium to long-term outcomes that have not been elucidated for these cases.

In this context, we highlight the effects of physical therapy, which is essential in the short, medium, and long term. Because physical therapy is a life sciences profession that studies, prevents, and treats functional kinetic disorders of bodily organs and systems resulting from genetic modifications, trauma, and acquired diseases (8), it plays an essential role in health care. Based on the assumptions above, the objective of this study was to report the experience of a group of physical therapists, professors at the Federal University of Santa Maria, in the rehabilitation of survivors of the Kiss nightclub tragedy.

\section{Materials and method}

This is an experience report of a group of physical therapists, professors at the Physical Therapy and Rehabilitation Department, from the Health Sciences Center of the Federal University of Santa Maria (UFSM), in the rehabilitation of victims of smoke inhalation injury and burns resulting from the fire at the Kiss nightclub. First, we introduce an investigation into the scientific research on the toxic effects of smoke inhalation, as well as possible after-effects of poisoning by $\mathrm{CO}$ and HCN in the medium and long term, due to the characteristics of the tragedy and in order to better support the victims. Electronic research was conducted on the PubMed, LILACS (Latin-American and Caribbean Center on Health Sciences Information), and SciELO (Scientific Electronic Library Online) databases.

The report is presented in the chronological order in which the events took place. Focus will be on voluntary assistance given by the group of physical therapy professors, both in local hospitals where victims were admitted immediately after the tragedy, and in the initial rehabilitation process.

Smoke inhalation injury

Smoke inhalation injury (SI) is characterized by acute pulmonary damage (9) that results from an inflammatory process in the airways that occurs after the inhalation of incomplete combustion products $(10,11)$. SIs play a major part in indoor fires (12) and are the main cause of early mortality (13). The mortality rate resulting from SI is very high, ranging from $60 \%$ to $80 \%$.

A study conducted by Park et al. (15) showed that SI triggers an inflammatory process in the airways with long-term pulmonary impairment and it may be associated with significant levels of morbidity and mortality. Previous studies addressed the effects of smoke inhalation on the respiratory system in the short term (16-19). Individuals who are exposed to smoke inhalation develop symptoms that are very similar to those of asthma, such as productive cough, tachypnea, and dyspnea (20). However, the literature has only few reports of medium - and long - term effects of smoke inhalation. 
Characteristics of poisoning by $\mathrm{CO}$ and $\mathrm{HCN}$

CO is an asphyxiating gas - colorless, odorless, tasteless, and nonirritant (21) - produced by incomplete combustion of hydrocarbons. Its concentration in the atmosphere is usually lower than $0.001 \%$ (22), and levels of only $1 \%$ are enough to result in severe injuries, due to the speed in which it is absorbed by the pulmonary epithelium, and its affinity with hemoglobin (23). Poisoning by CO accounts for $80 \%$ of deaths related to inhalation injuries, which occur mostly within the first 24 hours of exposure (24).

As for $\mathrm{HCN}$, it is a very volatile compound that is formed during fires by the incomplete combustion of carbonaceous and nitrogen - based materials such as cotton, silk, wood, paper, plastics, sponges, acrylics, and synthetic polymers in general $(24,25)$. In addition to this, recycling of pyrolysis products in closed environments increases the generation rate of these gases, and a poorly ventilated room may increase the generation rate as much as 10 times (24). HCN is characterized by its ability to bind to iron ions and it is carried through the bloodstream by red blood cells. In the intracellular environment, it binds to an enzyme, cytochrome $\mathrm{C}$ oxidase, completely blocking the respiratory cycle and consequently the formation of ATP. Therefore, intense lactic acidosis occurs, resulting in death after a few minutes of exposure to high levels (26).

During this research, it was found that it is not possible to predict the pathophysiological interactions of all toxins produced by smoke, especially if we consider the wide variety of components involved in pyrolysis, as well as the unpredictable generation rate of sub-products, which depends on the temperature, area, and composition of the environment (27). Another issue to be considered is that inhalation injury triggers an inflammatory process of the airways that results in long-term pulmonary impairment, and it may be associated with significant rates of morbidity-mortality (28). A recent study showed that survivors of poisoning by $\mathrm{CO}$ have higher mortality rates in the long term when compared to the general population (29).

As for the late neurological effects of poisoning by $\mathrm{CO}$ and $\mathrm{HCN}$, especially due to the direct effect of HCN on the central nervous system, some studies have shown that changes in personality may occur, as well as anxiety, paresthesia, memory disorders, and extrapyramidal syndromes $(30,31)$.
Organization of assistance to victims

On the day of the tragedy, the astonished population mobilized itself into different work fronts to put order to the chaos in the best possible way. Health professionals from the city, the region, and even from other states joined forces to provide care to the victims, in the transfer of patients, and in the search for equipment, especially those for ventilation support. At the same time, an SUS task force was established to ensure the provision of emergency services and structure for the adequate treatment of survivors.

In view of this context, physical therapists were called through social networks and by telephone to head to the hospitals. In addition to the victims who were hospitalized immediately after the fire, many others evolved to respiratory insufficiency over the course of the day as a result of the inhalation of toxic gases, needing hospitalization and respiratory physical therapy.

In the following weeks, the Integrated Care Center for Accident Victims (CIAVA, as per its acronym in Portuguese) was set up at the University Hospital of Santa Maria, in partnership with the Life Sciences Center, the Federal University of Santa Maria, the Health Regional Coordination Unit, the State Secretariat of Health, the City Secretariat of Health of Santa Maria, the Ministry of Health, and the Ministry of Education. The main reason for the creation of this center was to welcome victims who had been discharged from the hospital, especially those who had come from other health services, and to assess and provide care to those who were having late symptoms, as well as to actively search for individuals who had inhaled toxic smoke and had not sought assistance.

CIAVA works in the outpatient facilities of the University Hospital and has a multi-professional team composed of professionals from various fields, such as clinical medicine, pulmonology, neurology, psychiatry, ophthalmology, nursing, occupational therapy, social services, physical therapy, speech-language pathology, pharmacy, and psychology, so as to have an interdisciplinary approach within a place that favors change and improvement, and comprehensive care of accident victims. The initial scheduling of victims was done upon spontaneous demand, by the health services, by collective effort calls, by calling the health care services hotline (136), by accessing the Ministry of Health website, or by bookings through the Fourth 
Regional Health Coordination Unit. In this initial phase, 405 individuals were examined and referred to special services according to their needs. Worthy of note is that, after this phase, CIAVA still evaluates and monitors individuals based on the organization of access flows, the systematization of work processes, and the creation and revision of initial protocols. According to the last survey, a total of 3,777 individuals were provided with health care services in the aftermath of the fire.

\section{Experiences in rehabilitation}

Physical therapy professors were in touch with the victims from the first hours after the event, working in the ICUs and emergency rooms of local hospitals, in cooperation with other health services professionals. At the same time, there was an effective political participation to create and implement actions for victim support and monitoring, in partnership with representatives of the SUS National Force, the state Secretariat of Health, the city Secretariat of Health, the UFSM, associations of health care professionals, and the classes and professors of the Health Sciences Center of UFSM.

Based on claims made by competent bodies and on evidence regarding the toxicity of the inhaled gases, the group urgently created a physical therapy evaluation protocol in which it could identify, in a fast and efficient way, the physical and functional ability of patients, and also identify their cardiopulmonary, physical-motor, dermatological, and neurological rehabilitation needs. This protocol was applied both to patients who were discharged and to those who did not need to be hospitalized but had inhaled toxic smoke, and also to professionals involved in the rescue of victims and removal of bodies, and to neighboring residents. It should be noted that this protocol was also intended to classify the after effects on individuals into medium and low complexity.

The assessments were made in the form of two collective care services that took place in March 2013, in addition to the regular service hours. According to the last survey, 270 patients were examined (147 men, mean age $26.72 \pm 9.5$ years), of whom approximately $70 \%$ presented with some kind of clinical alteration or functional impairment that suggested the need for rehabilitation. The most prevalent respiratory signs and symptoms were: dry and/or productive cough
(59.2\%); change in respiratory pace $(11.4 \%)$; fatigue (35.92\%); dyspnea (17.7\%); and chest pain (16.6\%). Some patients also had neurological symptoms such as persistent headaches $(88.51 \%)$, memory loss (11.4\%), and paresthesia (8.1\%). Musculoskeletal injuries (14.7\%) and extensive burns (8.8\%) were also observed. One hundred and eighty-nine patients were referred to outpatient physical therapy treatment, of whom 22 remain at the Outpatient Physical Therapy Unit of the University Hospital as of today.

\section{Conclusions}

The experience has highlighted, among health professionals, the importance of joining forces within an emergency care unit, as well as the importance of comprehensive and multi-professional outpatient monitoring. This was essential in the care and rehabilitation processes of the direct and indirect victims of the tragedy, as a means of minimizing the physical and emotional suffering of these patients and their relatives.

Despite the vast experience of this group of physical therapists, the situations experienced were unique and unprecedented, both professionally and personally. Having dealt with so many losses, as well as the chaotic situation that prevailed in the city with its psycho-emotional aftershocks and the need for professional rationality, professionals had to face the situation with strength and determination. They were confronted with new challenges every day, and the need to overcome these difficulties resulted in unity within the group, emotional control, responsibility and professional discipline, as they set aside vanity and showed sensibility, earning the appreciation of those they helped.

\section{References}

1. Albuquerque IM, Pasqualoto AS, Trevisan ME, Gonçalves MP, Badaró AFV, Moraes JP, et al. Role of physiotherapy in the rehabilitation of survivors of the Kiss nightclub tragedy in Santa Maria, Brazil. Physiotherapy. 2013;99(4):269-70. 
2. Dal Ponte ST, Dornelles CF, Arquilla B, Bloem C, Roblin P. Mass-casualty response to the Kiss nightclub in Santa Maria, Brazil. Prehosp Disaster Med. 2015; 30(1):93-6.

3. Antonelo, L. Laudo confirma que queima de espuma em incêndio na Kiss liberou cianeto. Diário de Santa Maria [Internet]. 2013 Marc [cited 2014 Jan 11]. Available from: http://tinyurl.com/nz2npmo.

4. Knauss P. A cidade como sentimento: história e memória de um acontecimento na sociedade contemporânea: o incêndio do Gran Circus Norte-Americano em Niterói, 1961. Rev. Bras. Hist. 2007; 27(53):25-54.

5. Atiyeh B. Brazilian kiss nightclub disaster. Ann Burns Fire Disasters. 2013;26(1):3.

6. Stewart CL. The fire at Coconut Grove. J Burn Care Res. 2015;36(1):232-5.

7. Ramos G, Flageat G, Queiroz G, Nacif G, Fiorentino R, Arata A, et al. Massive hospital admission of patients with respiratory failure resulting from smoke inhalation injury: the Cromagnon Republic Tragedy. J Burn Care Res. 2006;27(6):842-7.

8. COFFITO [Internet]. Definição de fisioterapia e áreas de atuação. [place unknown], [plubisher unknown], [date unknown] [cited 2014 Jan 11]. Available from: http://www.coffito.org.br

9. Zhu F, Wang J, Qiu X, Li J, Xia Z. Smoke inhalation injury repaired by a bone marrow-derived mesenchymal stem cell paracrine mechanism: Angiogenesis involving the Notch signaling pathway. J Trauma Acute Care Surg. 2015;78(3):565-72.

10. Varon J, Marik PE, Fromm RE Jr, Gueler A. Carbon monoxide poisoning: a review for clinicians. J Emerg Med. 1999;17(1):87-93.

11. Gonçalves MP, Pasqualoto AS, Albuquerque IM, Trevisan ME. Cuidados agudos no paciente com lesão por inalação de fumaça. In: Associação Brasileira de Fisioterapia Cardiorrespiratória e Fisioterapia em Terapia Intensiva; Martins JA, Andrade FMD, Dias CM, organizadores. PROFISIO Programa de Atualização em Fisioterapia em Terapia Intensiva Adulto: Ciclo 5. Porto Alegre: Artmed Panamericana; 2014. p. 109-43. SECAD;1.
12. Bassi E, Miranda LC, Tierno PF, Ferreira CB, Cadamuro FM, Figueiredo VR, et al. Assistance of inhalation injury victims caused by fire in confined spaces: what we learned from the tragedy at Santa Maria. Rev Bras Ter Intensiva. 2014;26(4):421-9.

13. Ryan CM, Schoenfeld DA, Thorpe WP, Sheridan RL, Cassem EH, Tompkins RG. Objective estimates of the probability of death from burn injuries. N Engl J Med. 1998;338(6):362-6.

14. O'Brien DJ, Walsh DW, Terriff CM, Hall AH. Empiric management of cyanide toxicity associated with smoke inhalation. Pre Hosp Disaster Med. 2011; 26(5):374-82.

15. Park GY, Park JW, Jeong DH, Jeong SW. Prolonged airway and systemic inflammatory reactions after smoke inhalation. Chest. 2003;123(2):475-80.

16. Cho SY, Woo KH, Kim JS, Yoon SY, Na JY, Yu JH, et al. Acute symptoms in firefighters who participated in collection work after the community hydrogen fluoride spill accident. Ann Occup Environ Med. $2013 ; 25(1): 36$.

17. Na JY, Woo KH, Yoon SY, Cho SY, Song IU, Kim JA, et al. Acute symptoms after community hydrogen fluoride spill. Ann Occup Environ Med. 2013;25(1):17.

18. Chacko J, Jahan N, Brar G, Moorthy R. Isolated inhalational injury: Clinical course and outcomes in a multidisciplinary intensive care unit. Indian J Crit Care Med. 2012;16(2):93-9.

19. Kim CH, Woo H, Hyun IG, Song WJ, Kim C, Choi JH, et al. Pulmonary function assessment in the early phase of patients with smoke inhalation injury from fire. J Thorac Dis. 2014;6(6):617-24.

20. Clark WR Jr. Smoke inhalation: diagnosis and treatment. World J Surg. 1992;16(1):24-9.

21. Ernst A, Zibrak JD. Carbon monoxide poisoning. N Engl J Med. 1998;339(22):1603-8.

22. Raub JA, Mathieu-Nolf M, Hampson NB, Thom SR. Carbon monoxide poisoning: a public health perspective. Toxicology. 2000;145(1):1-14.

23. Anseeuw K, Delvau N, Burillo-Putze G, De Iaco F, Geldner G, Holmström P, et al. Cyanide poisoning by fire smoke inhalation: a European expert consensus. Eur J Emerg Med. 2013;20(1):2-9. 
24. Barillo DJ. Diagnosis and treatment of cyanide toxicity. J Burn Care Res. 2009;30(1):148-52.

25. Hamel J. A review of acute cyanide poisoning with a treatment update. Crit Care Nurse. 2011;31(1):7281; quiz 82.

26. Lawson-Smith P, Jansen EC, Hyldegaard O. Cyanide intoxication as part of smoke inhalation: a review on diagnosis and treatment from the emergency perspective. Scand J Trauma Resusc Emerg Med. 2011;19-14.

27. Antonio AC, Castro PS, Freire LO. Smoke inhalation injury during enclosed-space fires: an update. J Bras Pneumol. 2013;39(3):373-81.

28. Hampson NB, Rudd RA, Hauff NM: Increased longterm mortality among survivors of acute carbon monoxide poisoning. Crit Care Med. 2009;37:1941-47.

29. McCall JE, Cahill TJ. Respiratory care of the burn patient. J Burn Care Rehabil. 2005;26(3):200-6.
30. Centers for disease control and prevention [Internet]. Facts about cyanide. Atlanta: [article/document]. [cited May 2013]. Available from: http://www.bt.cdc. gov/agent/cyanide/basics/facts.asp. Jun 272013.

31. Mohan A, Lee T, Sachdev P. Surviving acute cyanide poisoning: a longitudinal neuropsychological investigation with interval MRI. BMJ Case Rep. 2014.

Received: 05/29/2014

Recebido: 29/05/2014

Approved: 04/14/2015

Aprovado: 14/04/2015 
